\title{
Lightweight high-strength concrete with the use of waste cenosphere as fine aggregate
}

\section{Concreto leve de alta resistência com uso de cenosfera de resíduo como agregado fino}

\author{
Felipe Basquiroto de Souza ${ }^{1,2}$, Oscar Rubem Klegues Montedo ${ }^{3}$,
} Rosielen Leopoldo Grassi ${ }^{1}$, Elaine Gugliemi Pavei Antunes ${ }^{1}$

\author{
${ }^{1}$ Department of Civil Engineering, Universidade do Extremo Sul Catarinense (UNESC), CP: 3167 - 88806-000, Criciú- \\ ma, Santa Catarina, Brasil. \\ ${ }^{2}$ Department of Civil Engineering, Monash University, VIC 3800, Clayton, Melbourne, Australia. \\ ${ }^{3}$ Programa de Pós-Graduação em Ciência e Engenharia de Materiais (PPGCEM), Universidade do Extremo Sul Catari- \\ nense (UNESC) CP: 3167 - 88806-000, Criciúma, Santa Catarina, Brasil. \\ e-mail: felipe.basquiroto@monash.edu, rosi.rosielen@gmail.com, elainegpa@unesc.net, oscar.rkm@gmail.com
}

\begin{abstract}
Cenosphere is a coal combustion by-product that presents interesting properties to be used in the production of cementitious materials, such as hollow structure, low density, low thermal conductivity and notably thermal stability. In addition, it displays pozzolanic reactivity under thermal curing. However, the cenosphere potential for the development of unique construction materials has not been fully investigated, remaining obscure for both power plants and the construction field. This study investigated the employment of waste cenosphere in partial substitution to sand for the obtainment of high-strength lightweight concrete materials. Cenosphere from a Brazilian power plant was chemically and physically characterized and the feasibility of its use in concretes was investigated. It was discovered that the power plant's fly ash is composed of approximately $0.2 \%$ of cenosphere. In addition, the cenosphere displayed size ranging from 30 to $300 \mu \mathrm{m}$ and were suitable for use as fine aggregate in concrete. Concrete with 33, 67, and 100\% fine aggregate replacement by the waste cenosphere was produced. Cenosphere-based high strength concrete presented strength higher than $70 \mathrm{MPa}$ and density as low as $1500 \mathrm{~kg} \cdot \mathrm{m}^{-3}$. Compared to mixes of reference, cenosphere application as fine aggregate improved the specific strength of high-strength concrete while maintaining equivalent mechanical properties.
\end{abstract}

Keywords: waste material; cenosphere; high strength concrete; lightweight cementitious materials.

\section{RESUMO}

Cenosfera é um sub-produto da combustão do carvão que apresenta interessantes propriedades para ser usado na produção de materiais cimentícios, tais como estrutura oca, baixa densidade, baixa térmica condutividade e notável estabilidade térmica. Além disso, ela mostra reatividade pozolânica na cura térmica. Entretanto, o potencial da cenosfera para o desenvolvimento de materiais de construção únicos não têm sido completamente investigados, permanecendo obscura para plantas de energia e no campo da construção. Este estudo investigou o emprego de cenosfera na substituição parcial à areia para a obtenção de materiais cimentícios de baixo peso. A cenosfera de uma planta de energia Brasileira foi química e fisicamente caracterizada e a viabilidade de seu uso em argamassas e concretos foi investigado. Foi descoberto que a cinza volante da planta de energia é composta de aproximadamente $0,2 \%$ de cenosfera. Além disso, a cenosfera exibe tamanho de partícula que varia de 30 a $300 \mu \mathrm{m}$ e era adequada para uso como agregado fino em concreto. Concretos com 33, 67 e $100 \%$ de substituição de agregados finos pela cenosfera de resíduos foram produzidos. Concreto baseado na cenosfera de alto desempenho apresentou resistência de até $70 \mathrm{MPa}$ e densidade tão baixa quanto 1500 $\mathrm{kg} \cdot \mathrm{m}^{-3}$. Em comparação com misturas de referência, a aplicação da cenosfera como agregado fino melhorou a resistência específica do concreto de alta resistência, mantendo propriedades mecânicas equivalentes. 
Palavras-chave: cenosfera; argamassas; concretos de alta resistência; materiais cimentícios de baixo peso.

\section{INTRODUCTION}

In the past few decades, great efforts have been made to reduce the amount of greenhouse gases (GHG) emission to the atmosphere with new alternatives for energy production. However, besides all investment on renewable solutions, the coal shares on global energy production is still significant [1]. Thus, recycling of byproducts from the coal industry, such as fly ash, is crucial. It is estimated that approximately 500 million tonnes of fly ash is annually produced in the world [2].

During the coal combustion, around 0.2 to $2 \mathrm{wt} \%$ of fly ash entrap large volume of air from the gas stream, causing the formation of hollow spherical-shaped particles called cenospheres [3-5]. Due to the hollow structure, they present low density (ranging from 400 to $900 \mathrm{~kg} \cdot \mathrm{m}^{-3}$ [6]) and low thermal conductivity. Cenospheres, similarly to fly ash, are aluminosilicates with $\mathrm{Si} / \mathrm{Al}$ ratio ranging from 1.5 to 3.5 [4]. When high amount of mullite is present, cenosphere displays notable thermal stability, low thermal expansion, high creep resistance, high resistance to crack propagation and high thermal shock resistance [7]. The yield of cenosphere is governed by the combustion temperature, fall distance, cooling rate and viscosity of the melt $[5,8]$.

Cenosphere presents great potential as aggregates for the fabrication of high-strength lightweight concrete. Lightweight concrete by use of lightweight aggregates has attracted great interest for structural applications due to reduction in concrete self-weight, which can reduce construction and transportation costs. Nevertheless, adequate selection of the aggregate in terms of high strength, low water absorption and compatible bond with cement matrix is crucial to the performance of high-strength lightweight concretes [43-45]. Cenospheres, on the other hand, presents excellent high crushing strength [40] and impermeable shell [46]. Furthermore, it has been demonstrated that cenosphere behaves as a pozzolan at higher temperatures $\left(80{ }^{\circ} \mathrm{C}\right)$, reacting with portlandite when mixed with Portland cement [13]. The pozzolanic activity can contribute to enhancing the interfacial bond between aggregate and cement matrix. Despite its reactivity under alkali environment, cenosphere does not show potential deleterious action in Portland cement based-mortars due to alkali-silica reaction [13]. Conventional strength cenosphere-based cement composites have been previously fabricated [10-12]. However, the fabrication of high-strength lightweight concrete containing cenosphere has been little explored in literature [6, 42].

Taking into account its unique physical and chemical properties, this paper investigates the feasibility of using waste cenosphere from a Brazilian coal-fired power plant as a fine aggregate for the obtainment of high-strength lightweight concrete. Figure 1 shows a schematic summarizing the performed research. Concrete with $33 \%, 67 \%$ and 100\% fine aggregate replacement by the waste cenosphere was produced. Due to the pozzolanic activity of cenosphere at higher temperatures, the effect thermal curing was also considered. In summary, cenosphere application as fine aggregate improved the specific strength of high-strength concrete materials while maintaining equivalent mechanical properties.

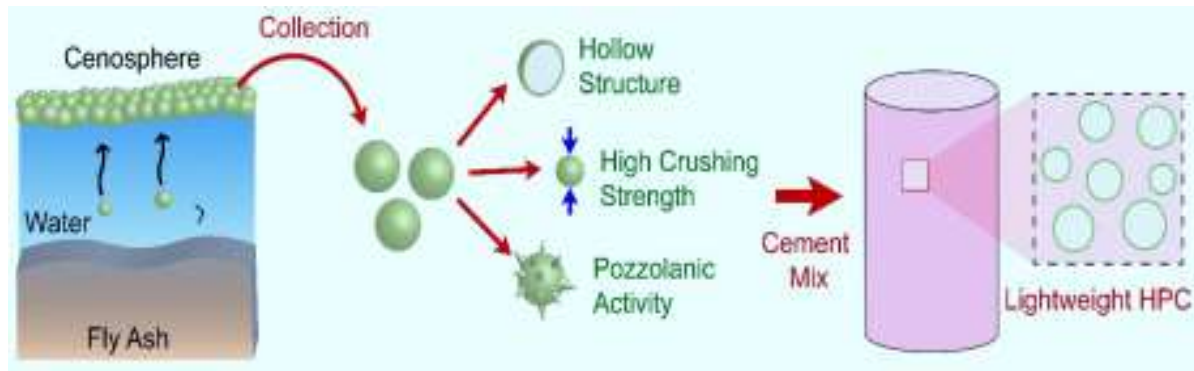

Figure 1: Schematic showing the collection, property characterization and application of waste cenosphere as fine aggregate in high-strength lightweight concrete.

\section{MATERIALS AND METHODS}

\subsection{MATERIALS}

Cenosphere was collected in a Brazilian coal-fired power plant from fly ash-rich effluent decantation deposit, Figure 2a. Fly ash samples from the combustion process batch had their cenosphere content measured by 
mixing $500 \mathrm{~g}$ of fly ash in water (Figure 2b). Since cenosphere particles emerge to the water surface, they can be easily collected and weighted. The collected cenosphere presented an average specific weight of $0.68 \mathrm{~g}$. $\mathrm{cm}^{-3}$ (approximately 4 times lower than the other aggregates used in concrete), $0.110 \mathrm{~m}^{2} \cdot \mathrm{g}^{-1} \mathrm{specific}$ surface area, $1.0 \times 10^{-3} \mathrm{~cm}^{3} \cdot \mathrm{g}^{-1}$ total pore volume for pores smaller than $68.1 \mathrm{~nm}$.

Portland cement type CP-IV class $25\left(3.16 \mathrm{~g} \cdot \mathrm{cm}^{-3}\right.$ specific weight), according to the Brazilian standard NBR 5736:1991 [15], was used in all mixtures. To the obtainment of the concretes, silica fume (2.26 g . $\mathrm{cm}^{-3}$ specific weight $)$, river washed sand $\left(2.48 \mathrm{~g} \cdot \mathrm{cm}^{-3}\right.$ specific weight $)$ and basalt gravel $\left(2.91 \mathrm{~g} \cdot \mathrm{cm}^{-3} \mathrm{spe}-\right.$ cific weight and maximum grain size of $8 \mathrm{~mm}$ ) were used.

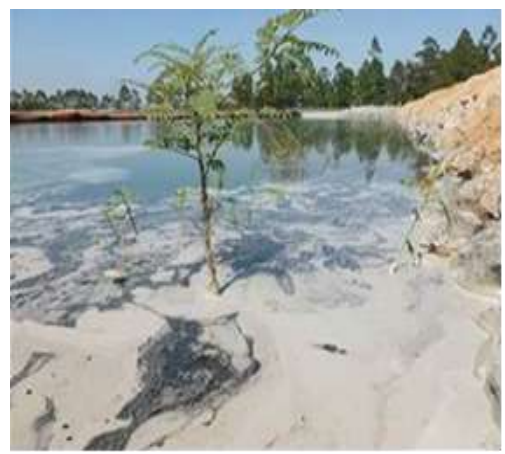

(a)

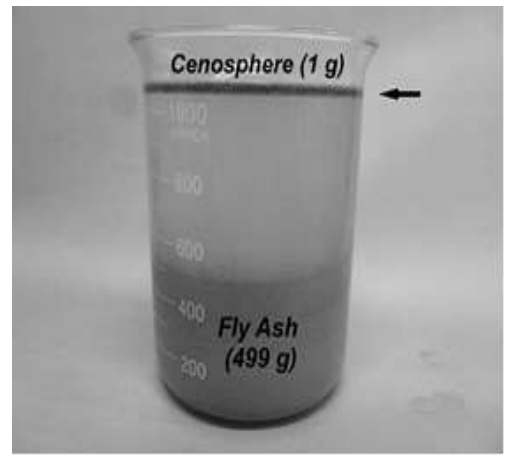

(b)

Figure 2: (a) View of the cenosphere-containing fly ash effluent decantation deposit showing the cenosphere-rich floating material. (b) The separation of cenosphere from the fly ash. The cenosphere is the floating layer and the fly ash is at the bottom of the Becker.

Superplasticizer Tec-Flow 8000 (GCP Applied Technologies, Brazil) $\left(1.08-1.12 \mathrm{~g} \cdot \mathrm{cm}^{-3}\right.$ ) was also used in the preparation of the concretes. USA).

The morphology of the cenosphere was observed in an optical microscope (Olympus BX41M-LED,

The particle size distribution of the cenosphere and fly ash was determined in a laser particle size analyser (1064L Cilas, France), while the sand granulometry was determined through sieving.

X-ray diffractometry (XRD) was performed in a Shimadzu Lab X XRD-6000 (Japan; Cu K $\alpha$ radiation, $2 \theta$ between 10 and $80^{\circ}, 1^{\circ} \cdot \mathrm{min}^{-1}$ scan rate and a step size of $0.02^{\circ}$ ) to determine the crystalline phases of cenosphere and fly ash. Loss on ignition (LOI) was determined according to Brazilian standard NBR NM [17] in a kiln at $950{ }^{\circ} \mathrm{C}$.

\subsection{OBTAINMENT OF THE CONCRETES}

The experimental design in mass and in relative volume for the obtainment of the concretes are in Table 1 and Table 2, respectively. Concrete with high compressive strength were attained by applying the following recommendations: small binder/aggregates ratio, high powder-packing, high amount of supplementary material (silica fume), water/binder ratio between 0.20 and 0.25 and high amount of superplasticizer [21-23].

Table 1: Experimental design in mass $\left(\mathrm{kg} \cdot \mathrm{m}^{-3}\right)$ for the obtainment of the concretes. Superplasticizer content $(2 \%)$ includes the mass of solids + liquid.

\begin{tabular}{|c|c|c|c|c|c|c|c|c|c|}
\hline \multirow[b]{2}{*}{ Batch } & \multicolumn{2}{|c|}{ Binder } & \multicolumn{3}{|c|}{ Aggregates } & \multirow[b]{2}{*}{ Water } & \multirow{2}{*}{$\begin{array}{c}\text { Super- } \\
\text { plasticizer }\end{array}$} & \multirow[b]{2}{*}{$\mathbf{w} / \mathbf{c}$} & \multirow{2}{*}{$\begin{array}{c}\text { Cure } \\
\text { temperature } \\
\left({ }^{\circ} \mathrm{C}\right)\end{array}$} \\
\hline & $\begin{array}{c}\text { Portland } \\
\text { cement }\end{array}$ & $\begin{array}{l}\text { Silica } \\
\text { fume }\end{array}$ & Sand & Cenosphere & Gravel & & & & \\
\hline HP0 & 732.4 & 244.1 & 1065.6 & - & 211.0 & 214.8 & $19.5(2 \%)$ & 0.22 & $23 / 80(72 \mathrm{~h})$ \\
\hline HP33 & 732.4 & 244.1 & 710.4 & 97.4 & 211.0 & 214.8 & $19.5(2 \%)$ & 0.22 & 23 \\
\hline HP67 & 732.4 & 244.1 & 355.2 & 194.8 & 211.0 & 214.8 & $19.5(2 \%)$ & 0.22 & 23 \\
\hline HP100 & 732.4 & 244.1 & - & 292.2 & 211.0 & 214.8 & $19.5(2 \%)$ & 0.22 & $23 / 80(72 \mathrm{~h})$ \\
\hline
\end{tabular}


In Table 1 and Table 2, the number in the batches' name indicates the cenosphere content in the compositions. For instance, the batch named HP67 presents 67 vol\% of cenosphere in substitution of sand.

Concretes were obtained by means of the following steps:

a) first, distilled water was mixed with the superplasticizer in the mixer;

b) cement and silica fume (previously dry mixed by hand) were then added over $10 \mathrm{~min}$;

c) aggregates (also previously mixed by hand) were added over $5 \mathrm{~min}$;

d) gravel was added to form the concrete;

e) the concrete was mixed for $5 \mathrm{~min}$ at $300 \mathrm{rpm}$, allowing the superplasticizer to disperse more effectively and increase the fluidity of the mixture.

Table 2: Experimental design in relation to volume of Portland cement.

\begin{tabular}{|c|c|c|c|c|c|c|c|}
\hline \multirow[b]{2}{*}{ Batch } & \multicolumn{2}{|c|}{ Binder } & \multicolumn{3}{|c|}{ Aggregates } & \multirow[b]{2}{*}{ Water } & \multirow{2}{*}{$\begin{array}{c}\text { Super- } \\
\text { plasticizer }\end{array}$} \\
\hline & $\begin{array}{c}\text { Portland } \\
\text { cement }\end{array}$ & $\begin{array}{l}\text { Silica } \\
\text { fume }\end{array}$ & Sand & Cenosphere & Gravel & & \\
\hline HP0 & 1.00 & 0.47 & 1.85 & - & 0.31 & 0.93 & 0.08 \\
\hline HP33 & 1.00 & 0.47 & 1.24 & 0.62 & 0.31 & 0.93 & 0.08 \\
\hline HP67 & 1.00 & 0.47 & 0.62 & 1.24 & 0.31 & 0.93 & 0.08 \\
\hline HP100 & 1.00 & 0.47 & - & 1.85 & 0.31 & 0.93 & 0.08 \\
\hline
\end{tabular}

Cylindrical specimens ( $5 \mathrm{~cm}$ diameter and $10 \mathrm{~cm}$ height) were casted in four layers. The samples were cured in $\mathrm{Ca}(\mathrm{OH})_{2}$ saturated solution at $23 \pm 1{ }^{\circ} \mathrm{C}$ until the test date. Casting procedures were performed according to the Brazilian standard NBR 7215:1996 [20]. Additional HP0 and HP100 specimens were thermally cured in $\mathrm{Ca}(\mathrm{OH})_{2}$ saturated solution at $80 \pm 1{ }^{\circ} \mathrm{C}$ for $72 \mathrm{~h}$ after demoulding. They were subsequently cured in water at $23 \pm 1{ }^{\circ} \mathrm{C}$ until the test date.

Compressive strength and modulus of elasticity tests were performed at the age of 28 days in accordance to the Brazilian standards NBR 5738:2003 [24] and NBR 8522:2008 [25], respectively.

The microstructure of the concretes was observed in a scanning electron microscope (SEM, Zeiss EVO-MA10 , Germany).

\section{RESULTS AND DISCUSSION}

\subsection{CENOSPHERE CHARACTERIZATION}

According to the Brazilian energy company, the daily average production of fly ash in this power plant is about 4,000 tonnes. The cenosphere is present into the fly ash and needs to be separated before it can be used. However, its collection will only be economically feasible if its content into the fly ash is high. The cenosphere content in the fly ash from the evaluated power plant was found to be approximately $0.20 \pm 0.02 \mathrm{wt} \%$ (0.6 vol\%).

It is thus estimated that 8 tonnes per day (over 2,900 tonnes per year) of cenosphere are lost in the evaluated power plant. As reference, in 2015, Brazil produced approximately 65 million tonnes of cement [26], which is significantly higher than the calculated amount of cenosphere available to be collected. However, the quantity of cenosphere is still substantial, and its separation can be justified for especial construction applications. A more extensive study is still needed to fully assess to what extent cenosphere can be employed in the construction field.

Figure 3a shows the quasi-spherical shape of the cenosphere particles, while Figure $3 \mathrm{~b}$ presents the particle size distribution of sand, cenosphere and fly ash.

Cenosphere particles range from 30 to $300 \mu \mathrm{m}$. The average particle size is approximately 27,100 and $230 \mu \mathrm{m}$ for sand, cenosphere and fly ash, respectively. Compared to the fly ash, the cenosphere particles are coarser and show roughly monodisperse distribution, indicating that only larger particles incorporate sufficient air to become less dense than water. On the other hand, the cenosphere is finer than the sand em- 
ployed in the concrete synthesis. For the same volumetric content of sand substitution, cenosphere can thus change the rheological properties of concrete.

The structural constitution of cenosphere and fly ash obtained by X-ray diffraction is shown in Figure 4. Quartz $\left(\mathrm{SiO}_{2}\right.$, JCPDS 46-1045) and mullite ( $\mathrm{Al}_{6} \mathrm{Si}_{2} \mathrm{O}_{13}$, JCPDS 15-0776) are the major crystalline phases present in the fly ash and cenosphere, respectively. Figure 4 also shows a wide band in the $20-40^{\circ} 2 \theta$ range in the X-ray scattering curve, which is typical for amorphous phase. The identified crystalline phases are important to estimate the behaviour of the material, such as the thermal stability, thermal expansion, creep resistance, resistance to crack propagation and thermal shock resistance.

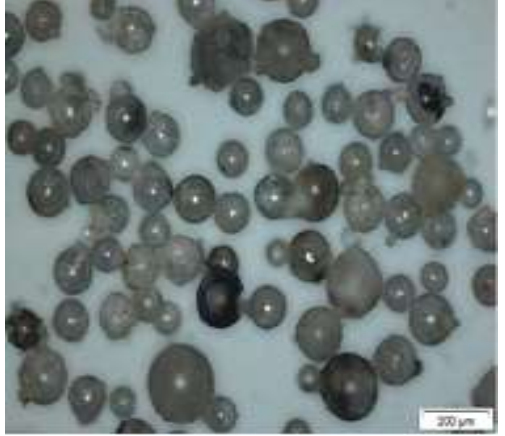

(a)

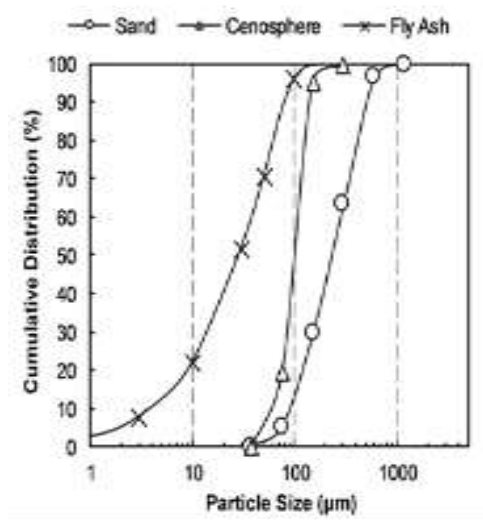

(b)

Figure 3: (a) Microscope image showing the morphology of the cenosphere particles. (b) Granulometric distribution of sand, cenosphere and fly ash particles.

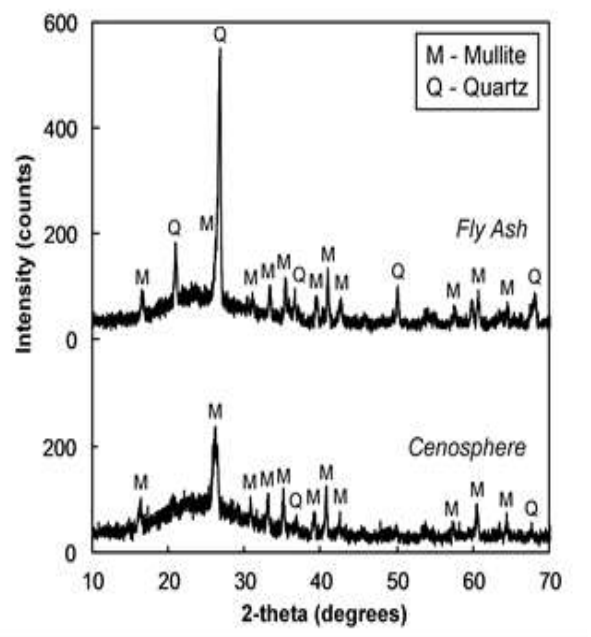

Figure 4: XRD patterns of the cenosphere and fly ash.

Considering that cenosphere is a by-product from coal combustion, residual organic compounds are expected to exist. Such compounds demand higher amount of water, affecting the workability of cementitious materials [27]. The cenosphere presented a loss on ignition (LOI) of $9.5 \pm 1.3 \%$, slightly above the limit stablished by the American standard ASTM C 618 (2015) [28] for class C and F fly ashes (6\%). The change in colour after $950{ }^{\circ} \mathrm{C}$ exposition is attributed to the destruction of carbonaceous compounds [29,30].

\subsection{HIGH STRENGTH LIGHTWEIGHT CONCRETES}

To analyse the feasibility of using waste cenosphere as a fine aggregate, high strength concrete with cenosphere incorporation was synthesized. Results of saturated density, oven dry density, compressive strength (CS), modulus of elasticity (E) and specific compressive strength (strength/density, $\mathrm{CS}_{\text {specific }}$ ) of all concretes 
are summarized in Table 3. Sand replacement by cenosphere was conducted at four distinct contents: 0\% (HP0), 33\% (HP33), 67\% (HP67) and 100\% (HP100).

Mixture HP0 was observed to be highly flowable, with workability comparable to self-compacting concrete. As sand was replaced by cenosphere in the mixture design, the workability of the concrete gradually reduced due to the smaller size of cenosphere. As a result, mixing became increasingly more difficult, and the HP100 batch had to be mixed for more $2 \mathrm{~min}$ at a speed of $400 \mathrm{rpm}$.

Table 3: Properties of high strength concretes with different cenosphere content.

\begin{tabular}{|c|c|c|c|c|c|c|c|}
\hline \multirow[b]{2}{*}{ Batch } & \multirow[b]{2}{*}{$\mathbf{w} / \mathbf{c}$} & \multicolumn{2}{|c|}{ Density $\left(\mathbf{k g} \cdot \mathbf{m}^{-3}\right)$} & \multicolumn{2}{|c|}{ CS at 28 days (MPa) } & \multirow{2}{*}{$\begin{array}{c}\mathrm{CS}_{\text {specific }} \\
\left(\mathrm{MPa} \mathrm{m}^{\mathbf{3}} \cdot \mathbf{k g}^{-\mathbf{1}}\right)\end{array}$} & \multirow[b]{2}{*}{$\mathbf{E}(\mathbf{G P a})$} \\
\hline & & Saturated & Dried & $\begin{array}{l}\text { Curing } \\
\text { at } 23^{\circ} \mathrm{C}\end{array}$ & $\begin{array}{l}\text { Curing at } 80^{\circ} \mathrm{C} \\
\text { for } 72 \mathrm{~h}\end{array}$ & & \\
\hline HP0 & 0.22 & 2346 & 2195 & 86.3 & 94.0 & 39.3 & 44.3 \\
\hline HP33 & 0.22 & 2134 & 1991 & 80.7 & - & 40.5 & - \\
\hline HP66 & 0.22 & 1912 & 1768 & 81.5 & - & 46.1 & - \\
\hline HP100 & 0.22 & 1650 & 1487 & 68.0 & 64.9 & 45.8 & 21.9 \\
\hline
\end{tabular}

Figure 5 demonstrates the compressive strength values of the high strength concretes. As it can be observed, compressive strength of the concretes was not affected up to $67 \%$ of cenosphere; a similar trend to that observed for mortars (previous section). More precisely, the HP67 concrete displayed only $6 \%$ reduction compared to HP0. HP67 also presented the highest specific strength among all batches. Such superior performance demonstrates the cenosphere, despite its hollowness, presents interesting mechanical behaviour under high loads, confirming its potential for the fabrication of lightweight high strength concrete.

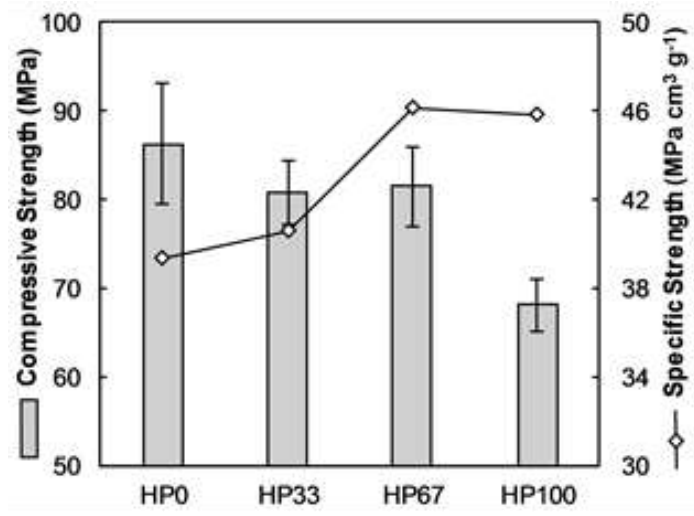

Figure 5: Compressive and specific strength of concrete with different cenosphere content: 0\% (HP0); 33\% (HP33); 67\% (HP67) e 100\% (HP100).

When sand was completely replaced by the cenosphere, concretes with approximately $1500 \mathrm{~kg} \cdot \mathrm{m}^{-3}$ density was obtained. However, the total replacement caused $21 \%$ loss in strength and slight decreased the specific strength. The HP100 inferior performance is explained by two complementary factors: 1) cenosphere particles are smaller than the washed river sand: coarser aggregates are fundamental for high strength concrete synthesis [23], and; 2) lower workability of the mixture, which presented several silica fume agglomerates. This lack of homogenization is demonstrated in Figure 6, which shows a silica fume agglomerate with size of approximately $500 \mu \mathrm{m}$ (larger than the neighbouring cenospheres) within the matrix. A longer mixing time would thus be necessary to homogenise these agglomerates.

Modulus of elasticity of HP0 and HP100 are shown in Figure 7. It is widely known that the modulus of elasticity of concrete is highly dependent on its aggregates properties [35,36]. Therefore, it was expected that the total replacement of sand by cenosphere (replacement of solids by voids) would reduce the material stiffness. Compared to HP0, the HP100 presented approximately 50\% loss of stiffness. Intermediate values would be expected for concrete with partial cenosphere incorporation (HP33 and HP67). 


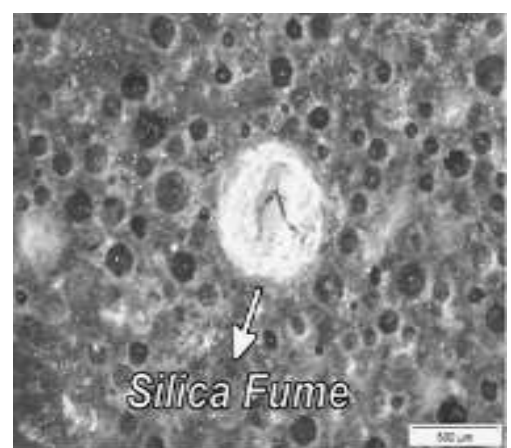

Figure 6: Silica fume agglomerate not adequately mixed to the matrix of a HP100 specimen.

Previous research revealed that cenosphere display pozzolanic reactivity at temperature of $80{ }^{\circ} \mathrm{C}$ [13]. To evaluate if the pozzolanic activity of cenosphere can yield positive effect on the mechanical properties of high-strength concrete, additional HP0 and HP100 samples were thermally cured at $80{ }^{\circ} \mathrm{C}$ for $72 \mathrm{~h}$ and had their compressive strength compared to samples constantly cured at $23{ }^{\circ} \mathrm{C}$. Thermal curing is commonly employed to high strength concrete to accelerate Portland cement reactions and obtain higher strength at early ages $[22,23]$. Results in literature demonstrate that thermal curing regimes from $24 \mathrm{~h}$ to $72 \mathrm{~h}$ with temperature range of $60-200^{\circ} \mathrm{C}$ can improve the mechanical properties of high-strength concrete [22, 47-49].

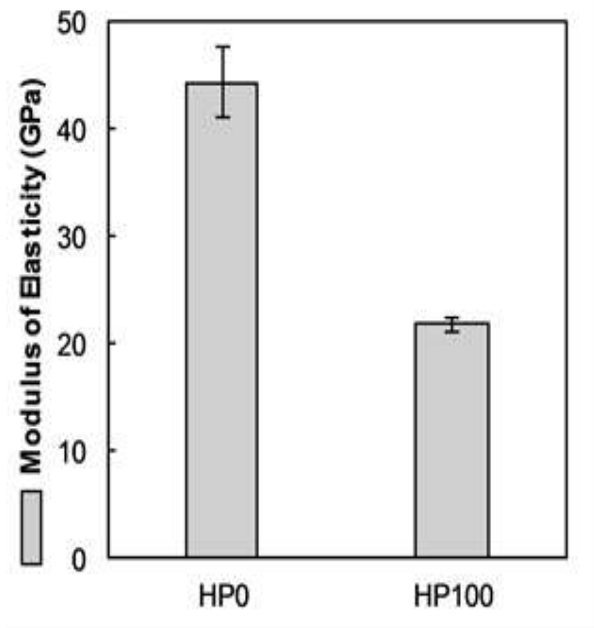

Figure 7: Modulus of elasticity of HP0 and HP100 concretes.

However, as shown in Figure 8, $72 \mathrm{~h}$ of thermal curing did not display any positive effect on the HP100 compressive strength. In fact, the obtained compressive strength was slightly smaller compared to samples cured at only $23{ }^{\circ} \mathrm{C}$. On the other hand, HP0 samples were improved by the higher curing temperature.

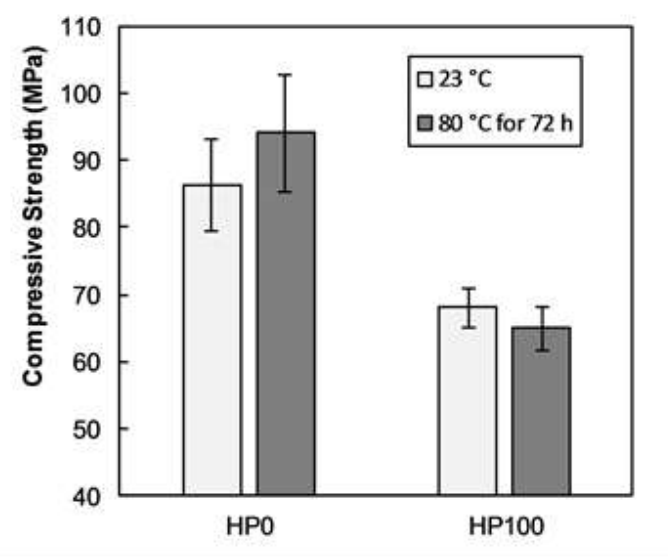

Figure 8: Thermal curing (72 h) influence on HP0 and HP100 compressive strength. 
To investigate the cenosphere chemical behaviour under thermal curing, SEM images of the HP100 concrete with and without curing treatment were obtained. As seen in Figure 9, the interior of the cenosphere shell from the concrete cured at room temperature is smooth and homogeneous (Figure 9a,b). In contrast, the formation of new crystals is observed in the interior of shells from thermally cured concretes (Figure 9c,d).
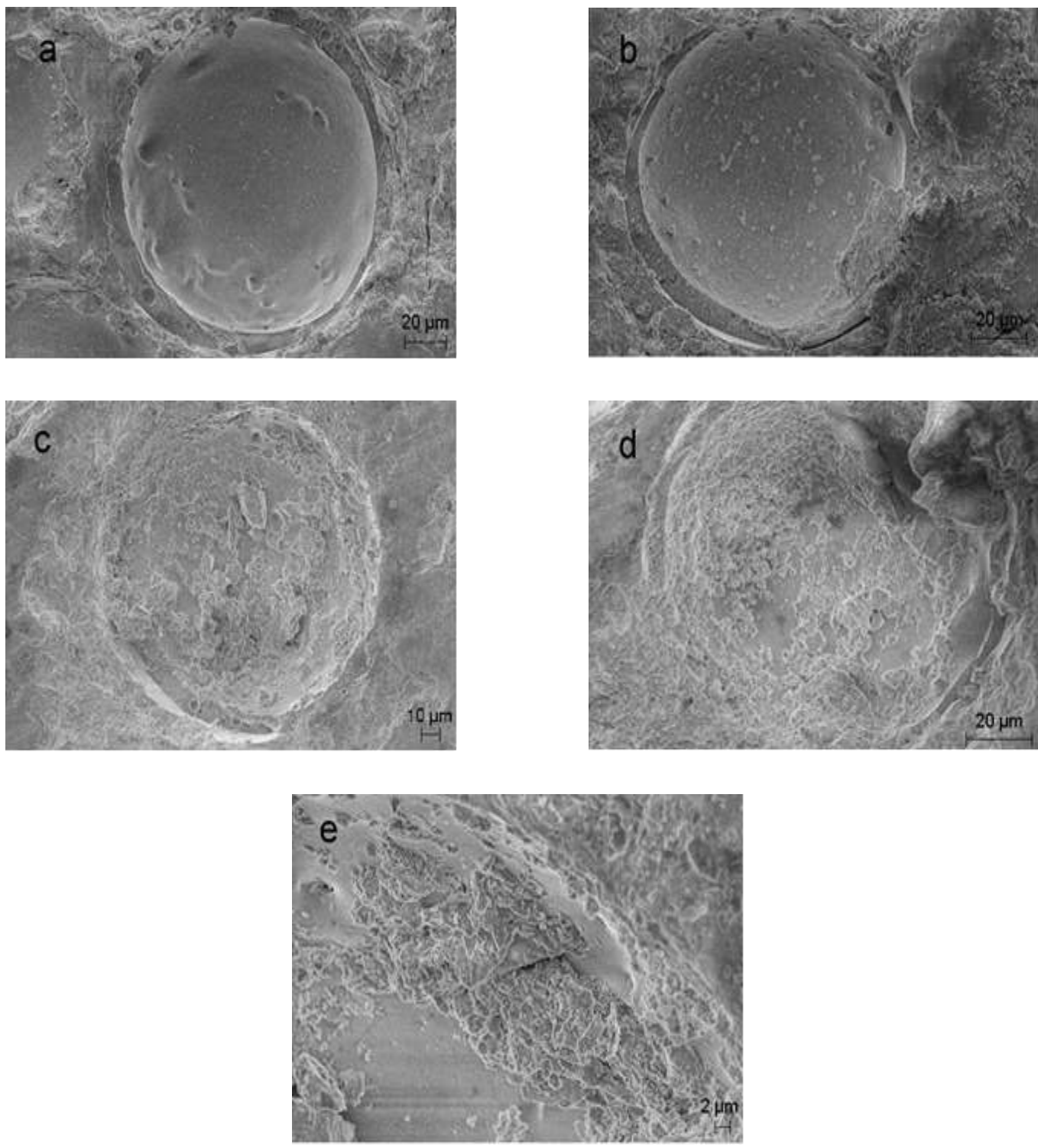

Figure 9: SEM images of the HP100 concrete cured at room temperature, (a) and (b), thermally cured at $80{ }^{\circ} \mathrm{C}$ for $72 \mathrm{~h}$, (c), (d) and (e).

The lack of defined shape of the formed products (Figure 9e) suggests they are calcium silicate hydrate $(\mathrm{C}-\mathrm{S}-\mathrm{H})$ precipitated as flakes. In addition, the interface between cenospheres and cement matrix in the thermally cured samples is not as visible as in the room temperature cured samples, further indicating the reaction between the by-product aggregate and the matrix.

To confirm if the formed crystals were a type of C-S-H compound and if they were a product of a pozzolanic reaction with the $\mathrm{Ca}(\mathrm{OH})_{2}$ from concrete, XRD analysis were performed with cenosphere particles after they were embedded in three different solutions: a supersaturated $\mathrm{Ca}(\mathrm{OH})_{2}$ solution, pure distilled water and a solution of distilled water and silica fume. The solutions were maintained at $80{ }^{\circ} \mathrm{C}$ for $72 \mathrm{~h}$, like the thermally cured concretes. Subsequently, the cenosphere samples were washed and dried in oven at 105 ${ }^{\circ} \mathrm{C}$. Figure 10 displays the XRD patterns of the three samples and compares to the pattern from a reference cenosphere (without thermal curing). 


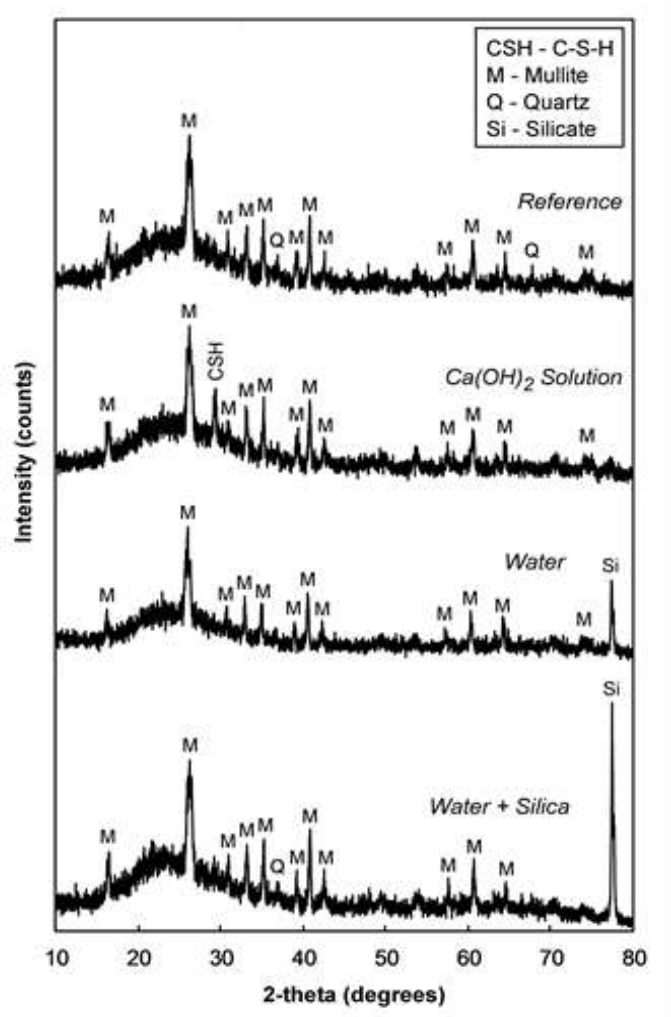

Figure 10: XRD diffraction of cenosphere treated at $80{ }^{\circ} \mathrm{C}$ for $72 \mathrm{~h}$ in three different conditions: $\mathrm{Ca}(\mathrm{OH})_{2}$ solution, pure distilled water and solution of distilled water plus silica fume. Comparison with reference cenosphere.

Interestingly, the cenosphere particles in $\mathrm{Ca}(\mathrm{OH})_{2}$ solution aggregated in a single large cluster after the thermal curing. When the cluster was broken, part of the particles did not float in water anymore. These facts imply that the cenosphere reacted and that the shell was modified during this reaction. This hypothesis is corroborated by the XRD analysis, Figure 10, which shows the rise of a characteristic peak for C-S-H $[37,38]$ after cenospheres were treated in $\mathrm{Ca}(\mathrm{OH})_{2}$ solution.

In absence of $\mathrm{Ca}(\mathrm{OH})_{2}$ (pure water), the XRD diffraction shows that temperature alone gives rise to a peak for a silica-rich phase [39]. This peak is further enhanced if silica fume is present in the solution. Diffractions of all solutions have their peaks for quartz broadened.

Therefore, it can be inferred that the reaction of cenospheres in thermally cured concrete occurs in a two-steps mechanism: first, part of the quartz is dissolved by the alkaline solution at high temperature. If a source of silica is present in solution, it is also absorbed by the cenosphere surface. Second, the dissolved silicates pozzolanically reacts with $\mathrm{Ca}(\mathrm{OH})_{2}$ from the pore solution of concrete, forming C-S-H-like precipitates.

Nevertheless, the new cementing products formation has not affected the concrete mechanical behaviour due to two possible reasons:

1) the C-S-H formation was only superficial. Thus, longer curing time would be necessary to produce a significant amount of binder that could influence the material macroscopic properties. In addition, the presence of silica fume in the mixture might have reduced the cenosphere reactivity, as it also consumes $\mathrm{Ca}(\mathrm{OH})_{2}$;

2) the formed products might have altered the chemical and physical characteristics of the cenosphere shell, which by itself presents a very high crushing strength [40].

\section{CONCLUSIONS}

Using waste cenosphere collected at a thermoelectric power plant, high-strength lightweight concrete with equivalent mechanical properties of the conventional density ones were produced. The studied cenosphere is a by-product composed by spherical particles with diameter ranging from 30 to $300 \mu \mathrm{m}$, consisted of approximately $9.5 \%$ of organic matter. The inorganic part is predominantly consisted of mullite. In addition, it was discovered that $0.2 \%$ by mass of the fly ash from the evaluated thermoelectric power plant are cenospheres. 
High-strength lightweight concrete was produced by sand replacement with cenosphere. It was found that $67 \mathrm{vol} \%$ of cenosphere significantly increased the specific strength of concrete. Concretes with $100 \mathrm{vol} \%$ sand substitution by cenosphere exhibited compressive strength of approximately $70 \mathrm{MPa}$ and density of only $1500 \mathrm{~kg} \cdot \mathrm{m}^{-3}$, with Young's modulus of approximately $22 \mathrm{GPa}$. After thermal curing of the cenosphere based-concrete, the by-product displayed certain pozzolanic activity, forming C-S-H-like precipitates. However, this reaction was not sufficient to affect the material properties. This study demonstrates that the application of this waste by-product as fine aggregates in high-strength concrete is feasible and has potential for production of structural lightweight cementitious materials.

\section{ACKNOWLEDGEMENT}

Special acknowledgement to Engie Energia for supplying the cenosphere throughout the research.

\section{BIBLIOGRAPHY}

[1] BP GLOBAL. BP Global Outlook: Outlook to 2035. https://www.bp.com/content/dam/bp/pdf/energyeconomics/energy-outlook-2016/bp-energy-outlook-2016.pdf. Access: November, 2016.

[2] AHMARUZZAMAN, M., "A review on the utilization of fly ash", Progress in energy and combustion science, v. 36, n. 3, pp. 327-363, 2010.

[3] GURUPIRA, T. Z., JONES, C. L., STENCEL, J. M., Cenosphere separation from fly ash using pneumatic transport, triboelectric processing, Center for Applied Energy Research, University of Kentucky, 1999.

[4] FOMENKO, E. V., ANSHITS, N. N., PANKOVA, M. V., et al., "Fly Ash Cenospheres: Composition, Morphology, Structure, and Helium Permeability", In: World of Coal Ash (WOCA) Conference, pp. 9-12, 2011.

[5] ŻYRKOWSKI, M., NETO, R. C., SANTOS, L. F., et al., "Characterization of fly-ash cenospheres from coal-fired power plant unit", Fuel, v. 174, pp. 49-53, 2016.

[6] WU, Y., WANG, J. Y., MONTEIRO, P. J., et al., "Development of ultra-lightweight cement composites with low thermal conductivity and high specific strength for energy efficient buildings", Construction and Building Materials, v. 87, pp. 100-112, 2015.

[7] CHÁVEZ-VALDEZ, A., ARIZMENDI-MORQUECHO, A., VARGAS, G., et al., "Ultra-low thermal conductivity thermal barrier coatings from recycled fly-ash cenospheres", Acta Materialia, v. 59, n. 6, pp. 2556-2562, 2011.

[8] WIBBERLEY, L. J., WALL, T. F., "An investigation of factors affecting the physical characteristics of flyash formed in a laboratory scale combustor", Combustion science and technology, v. 48, n. 3-4, pp. 177190, 1986.

[9] ARIZMENDI-MORQUECHO, A., CHÁVEZ-VALDEZ, A., ALVAREZ-QUINTANA, J., "High temperature thermal barrier coatings from recycled fly ash cenospheres", Applied Thermal Engineering, v. 48, pp. 117-121, 2012.

[10] MCBRIDE, S. P., A. SHUKLA, BOSE, A., "Processing and characterization of a lightweight concrete using cenospheres", Journal of Materials Science, v. 37, n. 19, pp. 4217-4225, 2002.

[11] WANG, J. Y., CHIA, K. S., LIEW, J. Y. R., et al., "Flexural performance of fiber-reinforced ultra lightweight cement composites with low fiber content", Cement and Concrete Composites, v. 43, pp. 39-47, 2013.

[12] BLANCO, F., GARCÍA, P., MATEOS, P., et al., "Characteristics and properties of lightweight concrete manufactured with cenospheres”, Cement and Concrete Research, v. 30, n. 11, pp. 1715-1722, 2000.

[13] WANG, J. Y., ZHANG, M. H., LI, W., et al., "Stability of cenospheres in lightweight cement composites in terms of alkali-silica reaction", Cement and Concrete Research, v. 42, n. 5, pp. 721-727, 2012.

[14] BIJU-DUVAL, P.M., A new porous material based on cenospheres, Master Dissertation. Georgia Institute of Technology, USA, 2007.

[15] ASSOCIAÇÃO BRASILEIRA DE NORMAS TÉCNICAS. NBR 5736: Cimento Portland pozolânico. Versão Corrigida:1999, 1991. 
[16] ASSOCIAÇÃO BRASILEIRA DE NORMAS TÉCNICAS. NBR 7214: Areia normal para ensaio de cimento - Especificação; 2015.

[17] ABNT NBR NM 18: Cimento Portland - Análise química - Determinação de perda ao fogo, 2012.

[18] ASTM C270-14a, Standard Specification for Mortar for Unit Masonry, ASTM International, West Conshohocken, PA, 2014.

[19] ASSOCIAÇÃO BRASILEIRA DE NORMAS TÉCNICAS. NBR 13279: Argamassa para assentamento e revestimento de paredes e tetos - Determinação da resistência à tração na flexão e à compressão, 2005 [Z].

[20] ASSOCIAÇÃO BRASILEIRA DE NORMAS TÉCNICAS. NBR 7215: Cimento Portland - Determinação da resistência à compressão. Versão Corrigida: 1997; 1996 [T].

[21] SCHMIDT, M., FEHLING, E., "Ultra-high-performance concrete: research, development and application in Europe", ACI Special publication, v. 228, pp. 51-78, 2005.

[22] RUSSELL, H. G., GRAYBEAL, B. A., "Ultra-high performance concrete: A state-of-the-art report for the bridge community", n. FHWA-HRT-13-060, 2013.

[23] CAMP, C., Design and Control of Concrete Mixtures. Chapter 17: High-Performance Concrete. http://www.ce.memphis.edu/1101/notes/concrete/PCA_manual/Chap17.pdf. Access: November, 2016.

[24] ASSOCIAÇÃO BRASILEIRA DE NORMAS TÉCNICAS. NBR 5738: Concreto — Procedimento para moldagem e cura de corpos de prova, 2015.

[25] ASSOCIAÇÃO BRASILEIRA DE NORMAS TÉCNICAS. NBR 8522: Concreto - Determinação do módulo estático de elasticidade à compressão, 2008.

[26] SNIC, Sindicato Nacional da Indústria do Cimento. Produção Nacional de Cimento por Regiões e Estados. http://www.snic.org.br/numeros/numeros.asp?path=ProducaoRegional2015.gif. Access: November, 2016.

[27] MOHEBBI, M., RAJABIPOUR, F., SCHEETZ, B. E., "Reliability of Loss on Ignition (LOI) Test for Determining the Unburned Carbon Content in Fly Ash", In: World of Coal Ash (WOCA) Conference, may 57,2015 .

[28] ASTM C618-15, Standard Specification for Coal Fly Ash and Raw or Calcined Natural Pozzolan for Use in Concrete, ASTM International, West Conshohocken, PA, 2015.

[29] SANTISTEBAN, J. I., MEDIAVILLA, R., LOPEZ-PAMO, E., et al., "Loss on ignition: a qualitative or quantitative method for organic matter and carbonate mineral content in sediments?", Journal of Paleolinology, v. 32, n. 3, pp. 287-299, 2004.

[30] FOX, J. M., "Changes in fly ash with thermal treatment", In: World of Coal Ash (WOCA) Conference, University of Kentucky, Lexington. 2005.

[31] TAYLOR, H. F. W., Cement chemistry. Thomas Telford, 1997.

[32] KODUR, V., "Properties of concrete at elevated temperatures", ISRN Civil engineering, ID 468510, 2014.

[33] DE SOUZA, A. A. A., MORENO JR., A. L., "Assessment of the influence of the type of aggregates and rehydration on concrete submitted to high temperatures", Revista IBRACON de Estruturas e Materiais, v. 3, n. 4, pp. 477-493, 2010.

[34] UYGUNOĞLU, T., TOPÇU, İ. B., "Thermal expansion of self-consolidating normal and lightweight aggregate concrete at elevated temperature", Construction and Building Materials, v. 23, n. 9, pp. 3063-3069, 2009.

[35] STOCK, A. F., HANNANTT, D. J., WILLIAMS, R. I. T. "The effect of aggregate concentration upon the strength and modulus of elasticity of concrete", Magazine of Concrete Research, v. 31, n. 109, pp. 225234,1979 .

[36] ZHOU, F. P., LYDON, F. D., BARR, B. I. G., "Effect of coarse aggregate on elastic modulus and compressive strength of high performance concrete", Cement and Concrete Research, v. 25, n.1, pp. 177-186, 1995.

[37] HOUSTON, J. R., MAXWELL, R. S., CARROLL, S. A., "Transformation of meta-stable calcium silicate hydrates to tobermorite: reaction kinetics and molecular structure from XRD and NMR spectroscopy", Geochemical Transactions, v. 10, n. 1, p. 1, 2009. 
[38] GUAN, W., JI, F., CHEN, Q., et al., "Synthesis and enhanced phosphate recovery property of porous calcium silicate hydrate using polyethyleneglycol as pore-generation agent", Materials, v. 6, n. 7, pp. 28462861, 2013.

[39] UMBARKAR, S. B., BIRADAR, A. V., MATHEW, S. M., et al., "Vapor phase nitration of benzene using mesoporous $\mathrm{MoO}_{3} / \mathrm{SiO}_{2}$ solid acid catalyst”, Green Chemistry, v. 8, n. 5, pp. 488-493, 2006.

[40] BARTAKE, P. P., SINGH, D. N., "Determination of crushing strength of cenospheres", Journal of ASTM International, v. 2, n. 7, pp 1-9, 2005.

[41] RANJBAR, N., \& KUENZEL, C. “Cenospheres: A review”, Fuel, v.207, pp.1-12, 2017.

[42] RHEINHEIMER, V., WU, Y., WU, T., CELIK, K., et al., "Multi-scale study of high-strength lowthermal-conductivity cement composites containing cenospheres", Cement and Concrete Composites, v.80, pp. 91-103, 2017.

[43] ATMACA, N., ABBAS, M. L., \& ATMACA, A. "Effects of nano-silica on the gas permeability, durability and mechanical properties of high-strength lightweight concrete", Construction and Building Materials, v.147, pp.17-26, 2017.

[44] MO, K. H., ALENGARAM, U. J., JUMAAT, M. Z. "Bond properties of lightweight concrete-a review”, Construction and Building Materials, v.112, pp. 478-496, 2016.

[45] ZHANG, M. H., GJVORV, O. E. "Mechanical properties of high-strength lightweight concrete", Materials Journal, v.88, n.3, pp. 240-247, 1991.

[46] LIU, F., WANG, J., QIAN, X., et al., "Internal curing of high performance concrete using cenospheres", Cement and Concrete Research, v.95, pp. 39-46, 2017.

[47] DE LARRARD, F., SEDRAN, T. "Optimization of ultra-high-performance concrete by the use of a packing model”, Cement and Concrete Research, v.24, n.6, pp. 997-1009, 1994.

[48] GARAS, V. Y., KAHN, L. F., KURTIS, K. E. "Tensile creep test of fiber-reinforced ultra-high performance concrete", Journal of testing and evaluation, v.38, n.6, pp. 674-682, 2010.

[49] PREM, P. R., BHARATKUMAR, B. H., IYER, N. R. "Influence of curing regimes on compressive strength of ultra high performance concrete", Sadhana, v.38, n.6, pp. 1421-1431, 2013.

\section{ORCID}

Felipe Basquiroto de Souza Oscar Rubem Klegues Montedo Rosielen Leopoldo Grassi Elaine Gugliemi Pavei Antunes https://orcid.org/0000-0001-9678-0256

http://orcid.org/0000-0002-3350-6732

https://orcid.org/0000-0002-1975-0376

https://orcid.org/0000-0002-9698-1100 